https://helda.helsinki.fi

Five approaches to pedagogical action research

\author{
Niemi, Reetta
}

2019

Niemi , R 2019 , ' Five approaches to pedagogical action research ' , Educational Action

Research , vol. 27 , no. 5 , pp. 651-666 . https://doi.org/10.1080/09650792.2018.1528876

http://hdl.handle.net/10138/313502

https://doi.org/10.1080/09650792.2018.1528876

acceptedVersion

Downloaded from Helda, University of Helsinki institutional repository.

This is an electronic reprint of the original article.

This reprint may differ from the original in pagination and typographic detail.

Please cite the original version. 
Corresponding author

Reetta Niemi

PhD, Lecturer, Viikki Teacher Training School, University of Helsinki

Research Associate, Faculty of Education, University of Johannesburg reetta.niemi@helsinki.fi 


\begin{abstract}
For decades teacher research, as one form of action research, has been a research methodology that combines theory, practice and improvement of practices in classrooms. However, the lack of teacher autonomy and trust in their professionalism reduces teachers' opportunities to conduct teacher research in their classrooms in many countries. Based on my 12-year-career as a pedagogical action researcher in Finland, in this paper I discuss five approaches to pedagogical action research, which is a specific form of teacher research that supports a strong model of professionalism. The approaches to pedagogical action research are: narrativity, pupils' agency, curriculum development, practical theories and ethics.

I give examples of each perspective and describe how these perspectives can be implemented. I also discuss how Finland's educational system in which primary school is decentralised, no teacher evaluation exists and the national curriculum offers teachers substantial pedagogical freedom supports implementing pedagogical action research in classrooms.
\end{abstract}

Keywords: pedagogy, teacher research, action research, pupils' agency 


\section{FIVE APPROACHES TO PEDAGOGICAL ACTION RESEARCH}

\section{Introduction}

Finnish educational policy respects the autonomy of teachers. Finnish teachers have more autonomy than do most teachers around the world (Sahlberg, 2011). Finland is also famous for its goal to educate teachers to be strong models of teacher professionalism, meaning teachers' skills to evaluate their own work and seek ways to improve it. For example, the University of Helsinki defines its goals in teacher education as follows:

The Degree Programme in Educational Sciences trains and educates teachers and other experts for positions that require expertise in education, schooling, teaching, learning, leadership, societal issues and educational sciences. The studies will also provide you with readiness to maintain and develop your professional skills and or academic post-graduate studies.

However, both global and national studies have shown that teachers, as well as student teachers, often feel that educational research or research-based education do not connect to their everyday work (Heikkinen, Kiviniemi \& Tynjälä 2011; Loughran 2002; Mitchell 2002). Thus, Heikkinen, Kiviniemi and Tynjälä (2011) have suggested that student teachers should be provided with an opportunity to conduct an action research project as part of their studies in Finland.

The organization of Finland's educational system allows teachers to conduct action research projects in their classrooms. In Finland, teachers' autonomy and trust in teachers' strong model of professionalism can be seen in many ways: primary school is decentralised, no teacher evaluation exists and the national curriculum offers teachers substantial pedagogical freedom (Lanas \& Kiilakoski 2013). For example, Cathy Caro-Bruce et al. (2013) have seen these elements as important in supporting teachers' professional development.

Teacher research as one form of action research, has been seen for decades as a research methodology that combines theory, practice and improvement of practices in classrooms 
(Elliot 2013; Loughran 2002; Mitchell 2002; Ponte \& Ax 2013; Rudduck \& Hopkins 1985). It has also been considered as a type of action research that should incorporate reflective teaching and critical reflective practice (Caro-Bruce et al. 2013; Lassonde \& Israel 2008).

In 1975, Lawrence Stenhouse launched teacher research. From his point of view, a theory of education is an articulation of teachers' shared practical understanding of how they make their practice in classrooms more educational through concrete, situated action (Elliott 2013). According to Cochran-Smith and Lytle (2009), teacher researchers work in their school communities, examine their own assumptions and develop local knowledge through research methods. Often these methods draw on biographical, autobiographical and narrative forms of data collection and analysis. In many versions of teacher research, the work is done to improve social justice in classrooms and ensure educational opportunity, access and equity for all pupils (Cochran-Smith \& Lytle 2009). Caro-Bruce et al. (2013) have also found that teacher research helps teachers to become more learner-centred and focus more on listening to pupils and have higher expectations for what their pupils know and can do.

From my perspective, in educational literature, there is one problem in terms of teacher research or classroom action research. Most cases, described in the literature, relate to specific action research projects in which teachers work together with academic researchers (e.g., Brennan 2013; Caro-Bruce et al. 2013; Lewis, Perry \& Friedkin 2013; Saunders \& Somekh 2013). What if an ordinary teacher wants to improve his/her own teaching through teacher research? How can teacher research be implemented in any classroom without being part of a research group?

I am a Finnish primary school teacher and I have worked as a teacher-researcher for more than a decade. In that time, I have not been part of any research group, but still I have conducted action research among 1st to 6th graders (7 to 13-year-old pupils) in two different school communities with three classrooms of my own. My doctoral studies took place in 2006-2007 in Kuusikko School in Vantaa, Finland. By the time of the study, Kuusikko School was an average-sized school with 350 pupils. Since then, I have done research at the Viikki Teacher Training School in Helsinki, which is a large, multicultural school with 950 pupils. During these years, my research questions have developed as follows: 1 . How do pupils experience the lived pedagogy of my classroom? 2. How do the methods used support pupils to express their experiences? 3. How do the methods used support pupils' participatory 
role in a research project and 4 . How do these findings help me and my pupils together to change classroom practices to improve social justice and ensure educational opportunity, access and equity for all pupils?

During my career, the greatest challenge has been a lack of methods that are suitable for pedagogical action research. In many cases, traditional research methods did not work and that failure has forced me to pay attention to methodological questions. In this paper, I describe pedagogical action research through five approaches. In many ways, my approaches follow the five principles for validating an action research narrative that were created by Hannu L.T. Heikkinen, Rauno Huttunen and Leena Syrjälä (2007). According to Heikkinen, Huttunen and Syrjälä (2007), a good action research narrative is historical as it first acknowledges the past course of events that have shaped the present practices (the principle of historical continuity); furthermore, it is reflexive (the principle of reflexivity) and elaborates the story dialectically (the principle of dialectics). A decisive criterion for successful action research is that it produces some useable practices that can be regarded as useful (the principle of workability). The principle of evocativeness relates to questions of how well the research narrative evokes mental images, memories or emotions related to the theme.

My meaning is not to separate pedagogical action research from educational action research or teacher research but rather to clarify the special characteristics that relate to pedagogical action research. I begin by discussing the concept of pedagogy. Then I present each approach separately and bring examples from my studies to show how each principle has worked in my pedagogical action research. In conclusion, I summarise the characteristics of pedagogical action research.

\section{A holistic conceptualisation of pedagogy}

The concept, 'pedagogy' is widely used among educators, without much consideration of its multifaceted nature. However, the meaning of the concept depends strongly on the context in which it is used. The Anglo-American version of pedagogy relates to a strong empirical research tradition for effective teaching and it often refers to teachers' presumptions and criteria or any conscious activity that they use to design and enhance learning in the 
classroom (e.g., Hinchliffe 2001; Loreman 2011; Waring \& Evans 2015; Watkins \& Mortimore 1999). A German version of pedagogy, on the other hand, is oriented towards the discussion of which values should inform education (Klitmøller 2017).

Leach and Moon (2008) define pedagogy as a dynamic process, informed by theories, beliefs and dialogues that is only realised in the daily interactions of learners and teachers in real settings. They also highlight Freire's work by defining pedagogy as a social process that extends to political arenas. Michael Waring and Carol Evans highlight Leach's and Moon's perspectives on pedagogy and present a holistic and integrated concept of pedagogy as described in Figure 1. According to Waring and Evans, an active and critical learner, who is enabled to make an informed and willing contribution to a just and democratic society, is at the centre of their model. Waring and Evans assert that in their model pedagogy is not a neutral landscape but 'a socially critical agenda, one in which notions of learner empowerment are framed by those power relationships that revolve around how knowledge is conceptualized and therefore is valued and how learners are positioned in relation to how knowledge is created as part of the pedagogical process' (Waring \& Evans 2015, 27-28). Waring and Evans say that their model promotes and informs democracy in education and in that sense, it joins forces with notions of critical pedagogy and the promotion of critical agents (Waring \& Evans 2015).

Figure 1. A holistic conceptualization of pedagogy by Waring and Evans $(2015,28)$ (developed from Penney \& Waring 2000)

In this paper, I use the holistic conceptualisation of pedagogy developed by Waring and Evans as a starting point in describing my ideas of pedagogical action research. This model contributes to both the Anglo-American and German traditions by highlighting questions about the incorporation of students' input in the deliberation of what is worthwhile in education.

\section{Approach to narrativity}


As Heikkinen, Huttunen and Syrjälä (2007) have said, action research reports are often narrative in nature. The reports may distinguish elements of narrativity: they focus on individual experiences, report these experiences chronologically and present a temporal sequence of events. Webster and Mertova (2007) also say that narrative inquiry attempts to capture the whole story, whereas other methods tend to communicate an understanding of studies, subjects or phenomena at certain points. I think that these two perspectives connect narrativity to the holistic conceptualization of pedagogy and pedagogical action research.

In my research, narrativity is embedded in collecting, analysing and reporting data. In data collection, I began by using learning diaries (Niemi, Heikkinen \& Kannas 2010). After the first study, I turned to the use of visual narratives, especially photographs, because I realized that writing narratives reduces some pupils' potential to express themselves and I had recognized pupils' interest in photographs. I also realized that previous studies had identified photographs as particularly helpful for pupils to document and communicate their perspectives of what constitutes a meaningful classroom experience (e.g., Clark 2010; Kumpulainen et al. 2013), to help pupils talk about their experiences instead of discussing something in the abstract (Cook \& Hess 2007) and to stimulate conversations in which participants share and consider different perspectives (Kaplan, Lewis \& Mumba 2007).

Narrative inquiry has also provided various methods in reporting pupils' voices but is it has also allowed me as a teacher or the parents of the pupils to be heard. For example, in Niemi, Heikkinen and Kannas (2010), I created a polyphonic web of stories and expressed experiences of pedagogy through three different voices: my voice as a teacher, your voice that represented pupils' experiences and their voice that represented parents' experiences. The next example illustrates your voice as pupils' experiences.

One day our teacher came to our class and she said that we have a serious problem in our school. Too many cars are driving in the mornings and in the afternoons to the school yard to bring or to pick up students. She asked if we had an idea what to do about the problem before an accident happens. We suggested that probably we could do some research into the situation and publish our results in the principal's paper sent monthly to homes. We also thought that probably we should also arrange a campaign around which class makes the least use of mechanical transport in getting to school. Then some of us went to have a discussion with the principal and she also thought that was a good idea. She 
also promised a prize for the class that gets to school by means involving the most physical exercise. Then we counted the traffic at the school yard for one week and made the report. Nelli, Anna and Hanna didn't like to count the traffic. They said it was boring, because during their shift there were no cars around. After the research, we had an opening ceremony of the 'Walk to school campaign'. It was really exciting that our class was the one to arrange it.

In pedagogical action research, narrative methods provide a fruitful way to represent and recount events by providing a structure for understanding and conveying the meaning of the experiences. They also support dialectics and polyphony or different voices (see: Heikkinen, Huttunen \& Syrjälä 2007) and provide a way to highlight educational values, raise questions and challenge prevailing discourses of education.

\section{Approach to pupils' agency}

In the core of the model presented by Waring and Evans, there is an active and critical learner. In the core of pedagogical action research there is an approach to promoting pupils' agency. This approach is also connected to the principle of workability by Heikkinen, Huttunen and Syrjälä (2007) where the principle of workability means that the evaluators of the quality of action research must pay attention to whether it has given rise to changes in social actions. My focus in evaluating the workability of my research has been on evaluating the workability of the tools to allow my pupils to express their experiences and support pupils' agency.

At the beginning of my career, my starting point was to find tools to listen to pupils' voices to understand their meaningful experiences. In the second phase of my career, my emphasis continued to be on developing methods for listening to pupils' voices; however, it turned into encouraging the participation of pupils in developing classroom practices. In the third phase of my career, the new turn is to include my pupils in the development of new research methods.

A major challenge in pedagogical action research in supporting pupils' agency relates to the workability of tools in engaging pupils' critical voices. A teacher always has a power relationship to pupils (e.g., Waring \& Evans 2015). That easily forces pupils to express only positive experiences. For example, in my earlier studies, both written narratives (Niemi, 
Heikkinen \& Kannas 2010) and photographs taken by pupils from their meaningful experiences (Niemi, Kumpulainen, Lipponen \& Hilppö 2015; Niemi, Kumpulainen \& Lipponen 2015a) launched primarily positive experiences. That reflection helped me develop the use of diamond ranking (e.g., O'Kane 2008; Clark 2012; Clark et al. 2013; Woolner et al. 2014) together with photographs to support the outcome of pupils' negative experiences and to engage them to change practices they did not like in our classroom.

A diamond-ranking activity, also known as 'diamond 9', has been developed and used by a British team to engage young people in the research process. The method involves a subset of nine photographs. The participants, working in pairs or threes, cut out these pictures and stick them onto a piece of paper in a diamond shape, ranking them by position so that the preferred picture is at the top and the most disliked is at the bottom. The participants also annotate the diamond with comments and explanations (Clark, 2012; Clark et al., 2013; Woolner et al., 2010, 2012, 2014).

In Niemi, Kumpulainen and Lipponen (2015b), I described how diamond ranking worked in order to also gather information about pupils' negative experiences and develop those practices.

Case 1: A weekly writing task. The pupils are required to complete a weekly writing task in the classroom. They have to write at least 20 sentences. In the 5 th grade, most of the topics are related to history because it is a new subject. The teacher uses the weekly writing task as a tool for learning history and writing in Finnish. In the first narratives, the weekly writing task was ranked mostly (7 out of 22) in the bottom row. (...) After the teacher had seen the diamonds and evaluated the first narratives, she brought up this topic in the classroom. The pupils and the teacher discussed what to do regarding the issue. For the teacher, it was important that the pupils did their writing; however, the issue was how to make it more convenient for the pupils. In a joint discussion, the pupils suggested that they be allowed to choose to do it with a pen and paper or on the computer. They also suggested giving the class more topics to choose from. They expressed their wish to write about more personal topics, which only the teacher would see; these would not be shared with other pupils. Therefore, [the] teacher changed the format of the weekly writing task according to the pupils' wishes.

That example shows that a diamond-ranking activity and written narratives worked as a tool to change classroom practices in the whole classroom community. However, that is only one perspective on change in practices. Through pedagogical action research, a teacher can make 
a change in one child's life as well. In Niemi, Kumpulainen, Lipponen and Hilppö (2015), I have described such an example:

The pupils generally felt that situations in which they were able to present their own learning were important and meaningful. One of the most important findings for the teacher was that one pupil, who she expected to enjoy presenting his accomplishments to other members of the classroom community, actually felt awkward about it. The following dialogue (Dialogue 7) illuminates this discussion.

Dialogue 7

Teacher: What do you mean by this picture?

Pupil: In this picture, we are teaching others.

Teacher: Is it exciting?

Pupil: No. I rather feel it awkward.

Teacher: That is quite a surprise to me. I have always thought that you like it because you are so good at presenting your learning. We have to discuss what we could do with that feeling.

The teacher in this study had taught the same class of pupils since the first grade. The method of taking photos and talking about them helped her to get to know her pupils as unique individuals. When the teacher discovered that one boy disliked presenting his learning, she had a discussion with him. They discussed how they could change the situation so that he would be more comfortable

As I see it, pedagogical action research is special as it turns the focus from teachers' pedagogical development to pupils' participatory role in educational change. Thus, I began my research as a teacher-researcher, but in recent years my work has evolved to pedagogical action research. The changes made in the classroom can relate not only to general practices but also to a single pupil. Both are to be seen as important. The most important factor in pedagogical action research is that pupils get to know that they have had a role in changes. As Emirbayer and Mische (1998) note, it is good for students to feel that activities in the classroom are not just happening to them but they can make a difference in the way they affect their lives.

\section{Approach to curriculum development}

The model by Waring and Evans (2015) raises the importance of understanding of the political agenda of pedagogy and policy in society. In their principles, Heikkinen, Huttunen 
and Syrjälä (2007) also emphasise awareness of the socio-historical frame of any action research project. In action research, it is important to recognise the historical evolution of the content both as a general macro-level phenomenon and as micro-level phenomenon that relates to historical, political and ideological trends. This idea is also supported by the ideas of Stephen Kemmis and colleagues concerning the reflexive-dialectical view on action research, which approaches action as a historically evolving process (e.g., Kemmis \& McTaggart 2000; Kemmis \& Wilkinson 1998).

In a school context, there is one factor that connects these elements: curriculum. In the name of historical continuity, curricula are to be seen as political documents that have a normative position and power in education. Curricula reflect values, changes in communities and politics (Apple 2001; Bailey 2006). For example, in my work the key question has been pupils' participation. Pupils' participation has received increased attention in the past decade after the ratification of the United Nations Convention on the Rights of the Child (UNCRC) (Alderson 2008; Landsdown 2010; Lundy 2007). In Finland, the recognition of children's rights to participation in the educational process has been institutionalized since 1998. The Basic Education Act 47 a $\S 1$ (1267/2013) states that children have a right to participate in the process of planning a curriculum. The strongest turn towards pupils' participation can be seen in the new national curriculum for basic education (FNBE, 2014) in which pupils' participation has had a central role.

The participatory turn in the Finnish educational discussion, has not only brought positive outcomes but also the concept of pupils' participation has become a canonical script that educators repeat by rote. Instead of being an analytical concept, it is lately referred to in any situations in which pupils work actively in groups (Tammi \& Hohti 2017). 'Self-help' books have even been developed for teachers to show how they can increase pupils' participation by promoting students' activity in lessons a few times per month (e.g., Luostarinen \& Peltomaa 2016).

I see that a pedagogical action researcher needs to be aware of the political agendas behind curriculum. For example, in my case, when the concept of pupils' participation has become a trendy concept, it has been even more important for me as a pedagogical action researcher, to clarify the history of the concept and bring analytical tools to teachers to understand its meaning in their own work To help teachers to understand the complex nature of 
participation, I created in co-operation with my co-writers a four-form-model for teachers to use as a tool to analyse the different forms of participation in classroom practices. I also described how these forms of participation occurred in one multidisciplinary learning module implemented in my own classroom. In the paper, I not only emphasised the importance of pupils' participation, I also directed attention to the preconditions of pupils' participation in a school context (Niemi, Kumpulainen \& Lipponen, 2018b).

\section{Approach to practical theories}

As Heikkinen, Huttunen and Syrjälä (2007) state, a good researcher is aware of his/her own knowledge; this is the principle of reflexivity. Waring and Evans (2015) also note that a holistic conception of pedagogy demands that teachers develop their interpretations of professionalism by exploring their conceptions of teaching, their view of knowledge and their commitment to professional development. I call that the reflexivity of practical theories.

In Finnish teacher education, the development of student teachers' practical theories has become one important target in the past couple of years. For example, at the University of Helsinki, student teachers begin to develop their practical theories in their first year at university and in teaching practice their practical theories work as mirrors when reflecting their pedagogical choices in their teaching (Maaranen et al. 2016; Stenberg et al. 2014). Because teachers use practical theory as a framework for their everyday work it also creates a mirror for teachers' reflections on their teaching (He and Levin 2008; Stenberg et al. 2014). Teachers' practical theory includes not only practical knowledge (i.e., managing a classroom, motivating pupils, accomplishing curriculum, conducting assessment, optimising conditions for learning and designing learning environments) but also their personal beliefs, values and understandings that guide their pedagogical actions in a classroom (Stenberg et al. 2014). The more clearly and coherently teachers structure their practical theory, the more developed that theory becomes (Buitnik 2009). In my studies, I have reflected on how my expectations and pupils' experiences have connected or become disconnected. In Niemi, Kumpulainen and Lipponen (2015a), I described this as follows:

In the second research cycle, there was a photograph from the teacher's own lesson. It was taken by a boy who did not take many pictures in either of the research cycles. He was engaged to take a picture 
from the mathematics lesson when he was able to work as a scientist and figure out a way to multiply with a double-digit. He explained that he had felt it meaningful because the teacher had not taught first, but had let the pupils invent new models for multiplying with a double-digit. He also said that problemsolving is a good way to learn when the task is suitable: neither too easy, nor too difficult. This made the teacher reflect critically on her basic assumptions about teaching certain subjects and she understood that she used the participatory model of teaching in project work, but she easily stuck with a teacher-oriented lesson model in mathematics and music. This awareness made her reflect on her teaching in all subjects. The experience made her understand that she had carried out a certain kind of idea of her pedagogy that was only true during certain lessons. It helped her to break down her assumptions and helped her to be more aware of alternative options to arrange lessons across the curriculum.

Pedagogical action research forces a teacher to structure his or her practical theory. When reporting pedagogical action research, a teacher's practical theory can be made explicit. For example, in many of my papers I have described how participatory pedagogy is defined in literature, how I emphasis certain aspects (i.e., narrative learning projects) and how I implement those goals in my work (e.g. Niemi, Kumpulainen \& Lipponen 2016). That aspect, however, brings challenges in reporting pedagogical action research; the papers easily take a descriptive form and it is difficult to meet the criteria traditionally set for an academic research. In order to meet the criteria, my research questions have often related to the tools that I have used and the workability of those tools in exploring pupils' experiences but at the same time each pedagogical action research initiative has allowed me to develop my practical theory.

\section{Approach to ethics}

For Heikkinen, Huttunen and Syrjälä (2007), the principle of workability also involves an ethical attitude. They say that a researcher needs to not only consider the practical consequences of research on the study subjects but also discuss these issues on a larger scale. From my perspective, ethical questions relate to the values of education and Waring's and Evans' (2015) idea to see pedagogy as a socially critical agenda where power relationships exist. In this section I will discuss a few specific dilemmas that a pedagogical action researcher must carefully consider at all stages of his or her research project.

In the literature, a researcher can find multiple lists to follow when doing teacher research 
with children (e.g., Bold 2012; Roberts 2008; Zeni 2013). When a researcher applies visual and narrative methodologies, he or she needs to be particularly sensitive to ethical concerns (Bold 2012; Mannay 2016). According to Zeni, the ethical standard of responsibility- the special trust that the teacher-researcher has to exercise among children and their parents while investigating issues in the classroom - most clearly distinguishes action research. The challenge in planning action research is to make the methods transparent (Zeni 2013).

In my studies, I have asked for official permission for my studies from the school principals. Then I have explained at a parents' evening what my research interests are and I have asked for written permission from the pupils' parents to allow data gathering stating, that I will ask for a separate permission to publish photographs from the pupils. I agree with Zeni (2013) that in action research full anonymity is almost impossible. Therefore, I have shown all photographs to both pupils and their parents. Pupils and parents have also been permitted to read and comment on my papers before I send them to publishers. They have also had the option of withdrawing from the research project at any time.

Mohr (2001) also noted that a teacher-researcher is first of all a teacher responsible to students, administrators, parents and the community; I agree; therefore, in my research I have paid careful attention to ensure that data collection has not: 1 . caused extra work for the pupils; 2. taken too much time from achieving other goals set in the curriculum; 3. created an unreasonable amount of work for the teacher-researcher and 4. required extra expense as the schools provided the equipment. At its best, pedagogical action research can provide teachers and teacher educators with knowledge about how different methods work to explore pupils' perspectives. Ethical research can and must be done as part of a normal school day and the use of time can be reported.

In my research, one turn was done because of that perspective. When I began to use photography as a tool to capture pupils' experiences, I borrowed six digital cameras from the faculty of education. During that spring, I realized that if I was not able to do that research with the equipment provided by my school, how could I assume that in every school and in every classroom, there would be six cameras to use to give teachers the tools to improve their practices. I also realized that I caused an unreasonable amount of work for myself with that method used in Niemi, Kumpulainen, Lipponen and Hilppö (2015). 
In my research, I have received criticism for not researching pupils' learning. That is an ethical choice. In my PhD thesis, I studied pupils' learning but I found that I had set the level for good learning and teaching very high. However, there are studies that prove that authorizing pupils' perspectives can directly improve educational practices (e.g., Dahl 1995; Cook-Sather 2002) and I no longer need to prove that listening to pupils and taking them into the process of improving classroom practices benefits their learning. Instead, I realized that ethical research must be transparent in describing how a learning project was implemented to give readers an opportunity to evaluate the quality of teaching. As said before, that makes pedagogical action research reports easily descriptive; however, these issues are important because of a sense of ethics.

At the core of a holistic conceptualization of pedagogy, there is an active and critical learner, who can feel a sense of agency and participate in the life of society (Waring \& Evans 2015). Ethical research, however, also respects pupils' rights not to participate or to choose their level of participation (e.g., Roberts 2008; Sinclair 2004). For example, in my latest study (Niemi, Kumpulainen \& Lipponen 2018a), in which data was collected through diamond ranking and peer interviews, there was one child who withdrew from giving an interview. The pupil did not complain about doing a peer interview but I noticed the child's awkward body language. When I asked if the pupil wanted to withdraw from doing an interview, the pupil nodded. I agree with Roberts (2008) that it is important, that pupils know that they can withdraw from research without penalty. When doing pedagogical action research, a teacher needs a sensitive eye to pupils' reactions and should understand that pupils express their wishes not only through words but also through body language and facial expressions.

A teacher-researcher always has a power relation to pupils (Fouché \& Chubb 2017). In my papers, I have tried to show how different tools have worked to give all my pupils ways to express themselves equally and to participate in the process of improving my classroom practices. In that sense, pedagogical action research should be seen as an educational process in which pupils are provided skills to affect their lives and feel a sense of participation.

\section{Conclusion}

In this paper, I have discussed how pedagogical action research is a specific form of teacherresearch through five approaches. The approaches are based on a holistic conceptualization of 
pedagogy (Waring \& Evans 2015) and five principles for validating action research (Heikkinen, Huttunen \& Syrjälä 2007). In this paper, I have presented these approaches separately, but in Figure 2 I have shown how they are they closely connected to each other.

Figure 2. Five approaches to pedagogical action research developed from Waring \& Evans $(2015,28)$

Firstly, pedagogical action research is narrative (approach to narrativity). It begins by listening to pupils and focusing on understanding their meaningful experiences. It also promotes polyphony by listening to other voices in a pedagogical relationship (teachers' or parents' voices) and through them raising questions about educational discourse or policy. Having an approach to pupils' agency, meaning how tools used in research promote pupils' different voices and how the methods used promoted pupils' agency in the classroom community, creates the core of pedagogical action research. In pedagogical action research, it is also important that the researcher knows the development of curriculum and understands both global and local perspectives and the political agendas behind curriculum (approach to curriculum development). Pedagogical action research forces a teacher to reflect on his or her practical theory and develop its structure (approach to practical theories). The approach to ethics relates to questions of the fairness of research and students' privacy, but also discusses issues related to the fairness of education in general.

My work has been recently questioned by Jacob Klitmøller (2017). He has asked whether pupils can evaluate a practice if they do not have a clear idea of the purpose of the practice or if they can be a relevant part of a discussion of educational values? From my perspective, these questions underestimate both teachers' tactfulness and pupils' capacities. I hope, that the examples described in this paper have shown that pupils are aware of what they are doing and they have had a real effect on classroom practices. In the General Comment No. 12 (2009), the UN committee states that views expressed by children may add relevant perspectives and experience and should be considered in decision-making, policymaking and law-makings and/or measures as well as their evaluation. The committee also states that exercise of the child's or children's right to be heard is a crucial element of such processes. The concept of participation emphasizes that including children should not be only a momentary act, but the starting point for an intense exchange between children and adults on 
the development of policies, programmes and measures in all relevant contexts of children's lives.

The special trust in teachers' autonomy has provided me with an excellent starting point to do pedagogical action research. Even though Finland gives great opportunities to teachers to conduct teacher research, there have been few research reports (doctoral thesis or research articles) conducted by in-service-teachers in Finland, perhaps due to teachers' lack of time. To support teachers to publish their work, there should be release time and funding for substitute teachers to give teachers time to write (see also, Caro-Bruce et al.2013). Teachers should also be provided with access to academic journals. Currently, that is only possible for teachers who work in teacher training schools. I believe that Finland offers a good example for other countries on how teacher-research can be supported through teachers' autonomy but Finland could also improve its system by supporting teacher research financially and making it easier for teachers to remain active in academic life.

In this paper, I have described my work through five approaches. I believe these approaches can be used in both teacher education and in-service teacher-training as a starting point when planning new pedagogical action research studies. I also hope that this paper will raise questions about how pedagogical action research could be used as a tool to educate student teachers towards ongoing professional development and how in-service-teachers could be provided opportunities to do pedagogical action research in their classrooms. Finally, I hope that this paper encourages those teachers, who already develop their work through teacher research but have not taken a step towards academic writing to take the next step and publish their work.

Acknowledgements: I thank graphic designer Joel Parsons for helping me create the figures presented in the paper. 
References:

Alderson, P. 2008. “Children as Researchers. Participation Rights and Research Methods. ” In Research with Children. Perspectives and Practices, edited by P. Christensen \& A. James, 276-290. Oxon: Routledge.

Apple, M.W. 2001. Educating the 'Right' Way. Markets, Standards, God and Inequality. London: Routledge.

Bailey, G.M.P. 2006. "Curriculum Narratives: The global dimension compared” in Narrative Research on Learning: Comparative and international perspectives, edited by S. Trahar, 129144. Oxford: Symposium Books.

Bold. C. 2012. Using Narrative in Research. London: SAGE Publications Ltd. Brennan, M. 2013. "A School System Takes on Exhibitions through Teacher Action Research." in The SAGE Handbook of Educational Action Research, edited by S. Noffke \& B. Somekh, 202-212. London: SAGE Publications Ltd.

Buitnik, J. 2009. What and how do student teachers learn during school-based teacher education? Teaching and Teacher Education 25: 118-127.

Caro-Bruce, C., M. Klehr, K. Zeichner and A.M. Sierra-Piedrahita. 2013 " A School DistrictBased Action Research Program in the United States." in The SAGE Handbook of Educational Action Research, edited by S. Noffke \& B. Somekh, 104-117. London: SAGE Publications Ltd.

Clark, A. 2010. Young children as protagonists and the role of participatory, visual methods in engaging multiple perspectives. American Journal of Community Psychology 46: 115-123. Clark, J. 2012. Using diamond ranking as visual cues to engage young people in the research process. Qualitative Research Journal 12(2): 222-237. 
Clark, J., K., Laing, L., Tiplady et al. (2013). Making Connections: Theory and Practice of Using Visual Methods to Aid Participation in Research. Newcastle upon Tyne: Research Centre for Learning and Teaching, Newcastle University.

Cochran-Smith, M. and S. L. Lytle. 2009. Inquiry as stance: Practitioner research for the next generation. New York: Teacher College Press.

Cook, T., and E. Hess. 2007. What the camera sees and from whose perspective. Fun methodologies for engaging children enlightening adults. Childhood 14 (1): 29-45.

Cook-Sather, A. 2002. Authorizing Students' Perspectives: Toward Trust, Dialogue, and Change in Education. Educational Researcher 31 (4): 3-14.

Dahl, K. 1995. Challenges in Understanding the Learner's Perspective. Theory into Practice 34 (2): 124-130.

Elliott, J. 2013. "Building Educational Theory through Action Research." in The SAGE Handbook of Educational Action Research, edited by S. Noffke \& B. Somekh, 28-38. London: SAGE Publications Ltd.

Emirbayer, M., and A. Mische. 1998. What is Agency? American Journal of Sociology, 103(4): 243-259.

Fouché C.B., and Chubb L.A. 2017. Action researchers encountering ethical review: a literature synthesis on challenges and strategies, Educational Action Research, 25:1, 23-34, DOI: 10.1080/09650792.2015.1128956.

He, Y., and B.B. Levin. 2008. "Match or Mismatch: How Congruent Are the Beliefs of Teacher Candidates, Teacher Educators, and Cooperating Teachers?" Teacher Education Quarterly 35 (4): 37-55.

Heikkinen, H., R., Huttunen, and Syrjälä, L. 2007. Action research as narrative: Five principles for validation. Educational Action Research 15 (1): 5-19. 
Heikkinen, H., U. Kiviniemi, and P. Tynjälä. 2011. "Integrative Pedagogy in Practicum: Meeting the Second Order Paradox of Teacher Education." In A Practicum Turn in Teacher Education, edited by M. Mattsson, T.V. Eilertsen and D. Rorrison, 91-112. Rotterdam: Sense.

Hinchliffe, G. 2011. Education or pedagogy? Journal of Philosophy of Education 35 (1): 3147.

Kaplan, I., I. Lewis, and P. Mumba. 2007. Picturing global educational inclusion? Looking and thinking across students' photographs from the UK, Zambia and Indonesia. Journal of Research in Special Educational Needs 7 (1): 23-35.

Kemmis, S. and R. McTaggart. 2000. "Participatory action research.” In Handbook of qualitative research, edited by N. Denzin \& Y. Lincoln, 567-606. London: SAGE publications Ltd.

Kemmis, S. and M. Wilkinson. 1998. "Participatory action research and the study of practice". In Action research in practice: partnership for social justice in education, edited by B. Atweh, S. Kemmis \& P. Weeks, 21-36. London: Routledge.

Klitmøller, J. 2017. Between 'pedagogy' and 'Pädagogik': a critique of lived pedagogy. Education 3-13, DOI: 10.1080/03004279.2017.1373138

Kumpulainen, K., L. Lipponen, J. Hilppö, and A. Mikkola. 2013. Building on the positive in children's lives: A co-participatory study on the social construction of children's sense of agency. Early Child Development and Care. doi:10.1080/03004430.2013.778253.

Landsdown, G. 2010. “The realisation of children's participation rights: critical reflections." In A Handbook of Children and Young People's Participation. Perspectives from Theory and Practice, edited by B. Percey-Smith \& N. Thomas, 11-23. Oxon: Routledge. 
Lanas. M., and T. Kiilakoski. 2013. "Growing Pains: Teacher Becoming a Transformative Agent.” Pedagogy, Culture and Society 21 (3): 343-360.

Lassonde, C.A., and S. E. Israel. 2008. Teachers Thinking Action. Newark, DE: International Reading Association.

Leach, J., and B. Moon. 2008. The Power of Pedagogy. London: SAGE Publications Ltd.

Lewis, C., R. Perry, and S. Friedkin. 2013 "Lesson Study as Action Research." in The SAGE Handbook of Educational Action Research, edited by S. Noffke \& B. Somekh, 142-154. London: SAGE Publications Ltd.

Loreman, T. 2011. Love as Pedagogy. Rotterdam: Sense Publishers.

Loughran, J. 2002. Researching Teaching for Understanding. in Researching Teaching: Methodologies and Practices for Understanding Pedagogy, edited by J. Loughran, 1-9. London: Routledge.

Lundy, L. 2007. Voice is not enough: conceptualising Article 12 of the United Nations Convention on the Rights of the Child. British Educational Research Journal 33 (6): 927-942.

Luostarinen, A., and I-M. Peltomaa. 2016. Reseptit OPSin käyttöön. PS-kustannus.

Maaranen, K., H. Pitkäniemi, K. Stenberg, and L. Karlsson. 2016. An idealistic view of teaching: Teacher students' personal practical theories. Journal of Education for Teaching: International Research and Pedagogy, 42(1), 80-92.

Mannay, D. 2016. Visual, Narrative and Creative Research Methods. Application, reflection and ethics. New York: Routledge. 
Mitchell, I. 2002. "Bridging the Gulf Between Research and Practice". in Researching Teaching: Methodologies and Practices for Understanding Pedagogy, edited by J. Loughran, 44-64. London: Routledge.

Mohr, M. M. 2001. "Drafting ethical guidelines for teacher research in schools”. In Ethical Issue in Practitioner Research, edited by J. Zeni, 3-12. Dordrecht: Kluwer.

The national core curriculum for Finnish preschool and basic education .2014. Available from: http://www.oph.fi/ops2016/perusteet [accessed 29 $9^{\text {th }}$ July 2018]

Niemi, R., H.L.T. Heikkinen, and L. Kannas. 2010. Polyphony in the classroom: reporting narrative action research reflexively. Educational Action Research, 18 (2), 137-149.

Niemi, R., K. Kumpulainen, and L. Lipponen. 2015a. Pupils as active participants: Diamond ranking as a tool to investigate pupils' experiences of classroom practices. European Educational Research Journal. 10.1177/1474904115571797

Niemi, R., K. Kumpulainen, and L. Lipponen, L. 2015b. Pupils' documentation enlightening teachers' practical theory and pedagogical actions. Educational Action Research 23 (4), 599614.

Niemi, R., K. Kumpulainen, and L. Lipponen. 2016. “Children's participation in a classroom: Turning the UN Convention on the Rights of the Child into pedagogical practices." In Children's Rights, Educational Research and the UNCRC; Past, present and future, edited by J. Gillet-Swan \& V. Coppock, 81-100. Oxford: Symposium Books.

Niemi, R., K. Kumpulainen, K, and L. Lipponen. 2018a. The use of a diamond ranking and peer interviews to capture pupils' perspectives. Improving Schools. $10.1177 / 1365480218774604$

Niemi, R., K. Kumpulainen, and L. Lipponen. 2018b. Osallistumista vai osallistamista? Osallisuuden tarkastelua monialaisen oppimiskokonaisuuden toteuttamisessa. Nuorisotutkimus 36 (1), 22-35. 
Niemi, R., Kumpulainen, K., Lipponen, L. \& Hilppö, J. 2015. Pupils' perspectives on the lived pedagogy of the classroom. Education 3-13, 681-697.

O’Kane, C. 2000. “The Development of Participatory Techniques. Facilitating Children's Views about Decisions which Affect Them”. In Research with Children. Perspectives and Practices, edited by in P. Christensen \& A. James, 125-155. Oxon: Routledge.

Penney, D., and M. Waring. 2000.” The Absent Agenda. Pedagogy and Physical Education.” Journal of Sport Pedagogy 6 (1): 4-37.

Ponte, P., and J. Ax. 2013. "Action Research and Pedagogy as Science of the Child's Upbringin.”. In The SAGE Handbook of Educational Action Research, edited by S. Noffke \& B. Somekh, 324-335. London: SAGE Publications Ltd.

Roberts, H. 2008. "Listening to Children: and Hearing Them”. In Research with Children. Perspectives and Practices, edited by P. Christensen \& A James, 260-275. Oxon: Routledge.

Rudduck, J., \& D. Hopkins. 1985. Research as a Basics for Teaching. Oxford: Heinemann.

Saunders, L., and B. Somekh. 2013 “Action Research as Educational Change: Teachers as Innovators". In The SAGE Handbook of Educational Action Research, edited by S. Noffke \& B. Somekh, 190-201. London: SAGE Publications Ltd.

Sahlberg. P. 2011. Finnish Lessons: What Can the World Learn from Educational Change in Finland. The Series on School Reform. New York: Teacher College Press.

Sinclair, R. 2004. "Participation in Practice: Making it Meaningful, Effective and Sustainable". Children and Society 18: 106-118. 
Stenberg, K., L. Karlsson, H. Pitkäniemi, and K. Maaranen. 2014. Beginning student teachers' teacher identities based on their practical theories. European Journal of Teacher Education, 37(2), 204-219.

Tammi, T., and R. Hohti. 2017. ’Lasten osallistuminen ja posthumanistinen ontologia: urittuvaa emergenttiä kartoittamassa". Kasvatus ja Aika 11 (1):69-83.

United Nations Convention on Rights of the Child. 1989. UN general assembly resolution 44/25. http://www.ohchr.org/EN/ProfessionalInterest/Pages/CRC.aspx [accessed 4.1. 2016].

UN Committee on the Rights of the Child (CRC), General comment No. 12. 2009. The right of the child to be heard, 20 July $2009, \mathrm{CRC} / \mathrm{C} / \mathrm{GC} / 12$. http://www.refworld.org/docid/4ae562c52.html [accessed 27 February 2018].

Waring, M., and C. Evans. 2015. Understanding Pedagogy. Developing a critical approach to teaching and learning. London: Routledge.

Watkins, C., and P. Mortimore. 1999. “Pedagogy: what do we know?” In Understanding Pedagogy and its Impact on Learning, 1-19. Edited by P. Mortimore. London: SAGE Publications Ltd.

Webster, L., and P. Mertova. 2007. Using narrative inquiry as a research method: An introduction to using critical event narrative analysis in research on learning and teaching. London: Routledge.

Woolner, P., Clark, J., Hall, E., Laing, K., Thomas, U. \& Tiplady, L. (2010) Pictures Are Necessary but Not Sufficient: using a range of visual methods to engage users about school design, Learning Environments Research, 13(1), 1-22. 
Woolner, P., Clark, J., Laing, K., Thomas, U. \& Tiplady, L. (2012) Changing Spaces: preparing students and teachers for a new learning environment, Children, Youth and Environments, 22(1), 52-74.

Woolner, P., Clark, J., Laing, K., Thomas, U. \& Tiplady, L. (2014) A School Tries to Change: how leaders and teachers understand changes to space and practices in a UK secondary school, Improving Schools, 17(2), 148-162

Zeni, J. 2013. "Ethics and the 'Personal' in Action Research". In The SAGE Handbook of Educational Action Research, edited by S. Noffke \& B. Somekh, 254-266. London: SAGE Publications Ltd. 